\section{geopolitics of gas} working paper series

\title{
MARKET STRUCTURE IN THE NEW GAS ECONOMY: IS CARTELIZATION POSSIBLE?
}

ronald soligo and amy myers jaffe 


\section{Market Structure in the New Gas Economy: Is Cartelization Possible?}

Ronald Soligo and Amy Myers Jaffe

May 2004

Prepared for the Geopolitics of Natural Gas Study, a joint project of the Program on Energy and Sustainable Development at Stanford University and the James A. Baker III Institute for Public Policy of Rice University. 


\title{
About the Program on Energy and Sustainable Development
}

The Program on Energy and Sustainable Development at Stanford University is an interdisciplinary research program focused on the economic and environmental consequences of global energy consumption. Its studies examine the development of global natural gas markets, reform of electric power markets, and how the availability of modern energy services, such as electricity, can affect the process of economic growth in the world's poorest regions. The Program also works on legal and regulatory issues surrounding the development of an effective international regime to address the issues of global climate change.

The Program, established in September 2001, includes a global network of scholars - based at centers of excellence on six continents-in law, political science, economics and engineering. The Program is part of the Center for Environmental Science and Policy, at the Stanford Institute for International Studies.

\author{
Program on Energy and Sustainable Development \\ At the Center for Environmental Science and Policy \\ Stanford Institute for International Studies \\ Encina Hall East, Room 415 \\ Stanford University \\ Stanford, CA 94305-6055 \\ http://pesd.stanford.edu \\ pesd-admin@lists.stanford.edu
}




\section{About the James A. Baker III Institute for Public Policy}

The Baker Institute Energy Forum is a multifaceted center that promotes original, forward-looking discussion and research on the energy-related challenges facing our society in the 21st century. The mission of the Energy Forum is to promote the development of informed and realistic public policy choices in the energy area by educating policy makers and the public about important trends -both regional and global-that shape the nature of global energy markets and influence the quantity and security of vital supplies needed to fuel world economic growth and prosperity.

The forum is one of several major foreign policy programs at the James A. Baker III Institute for Public Policy at Rice University. The mission of the Baker Institute is to help bridge the gap between the theory and practice of public policy by drawing together experts from academia, government, the media, business, and non-governmental organizations. By involving both policy makers and scholars, the Institute seeks to improve the debate on selected public policy issues and make a difference in the formulation, implementation, and evaluation of public policy

The James A. Baker III Institute for Public Policy

Rice University-MS 40

P.O. Box 1892

Houston, TX 77251-1892

http://www.bakerinstitute.org

bipp@rice.edu 


\section{About the Geopolitics of Natural Gas Study}

Natural gas is rapidly gaining in geopolitical importance. Gas has grown from a marginal fuel consumed in regionally disconnected markets to a fuel that is transported across great distances for consumption in many different economic sectors. Increasingly, natural gas is the fuel of choice for consumers seeking its relatively low environmental impact, especially for electric power generation. As a result, world gas consumption is projected to more than double over the next three decades, rising from $23 \%$ to $28 \%$ of world total primary energy demand by 2030 and surpassing coal as the world's number two energy source and potentially overtaking oil's share in many large industrialized economies.

The growing importance of natural gas imports to modern economies will force new thinking about energy security. The Energy Forum of the James A. Baker III Institute for Public Policy and the Program on Energy and Sustainable Development at the Stanford University Institute for International Studies are completing a major effort to investigate the geopolitical consequences of a major shift to natural gas in world energy markets. The study utilizes historical case studies as well as advanced economic modeling to examine the interplay between economic and political factors in the development of natural gas resources; our aim is to shed light on the political challenges that may accompany a shift to a gas-fed world.

\section{Disclaimer}

This paper was written by a researcher (or researchers) who participated in the joint Baker Institute/Stanford PESD Geopolitics of Natural Gas Study. Where feasible, this paper has been reviewed by outside experts before release.

However, the research and the views expressed within are those o the individual researcher(s), and do not necessarily represent the views of the James A. Baker III Institute for Public Policy or Stanford University. 


\section{About the Authors}

Ronald Soligo is professor of economics at Rice University. His research focuses on economic growth and development and energy economics. Dr. Soligo was awarded the 2001 Best Paper Prize from the International Association for Energy Economics for his co-authored paper with Dr. Kenneth B. Medlock III "Economic Development and End-Use Energy Demand,” Energy Journal, April (2001). Other recently published articles include: "The Role of Inventories in Oil Market Stability”, with Amy Myers Jaffe, Quarterly Review of Economics and Finance. "Automobile Ownership and Economic Development: Forecasting Passenger Vehicle Demand to the Year 2015”, with Kenneth B. Medlock III, Journal of Transport Economics and Policy. "The Economics of Pipeline Routes: The Conundrum of Oil Exports from the Caspian Basin”(with Amy Myers Jaffe), in Energy in the Caspian Region: Present and Future, Amy Myers Jaffe, Yelena Kalyuzhnova, Dov Lynch and Robin Sickles, editors. Dr. Soligo is currently working on research on OPEC and the Gas Forum for Exporting Countries. He holds a doctorate degree from Yale University.

Amy Myers Jaffe, president of AMJ Energy Consulting, is the associate director of the Rice University energy program and Wallace S. Wilson Fellow for Energy Studies at the James A. Baker III Institute for Public Policy of Rice University. She is a principal author of the Institute's first nine energy studies. She was a contributor to the joint Baker Institute/Council on Foreign Relations (CFR) task force on Guiding Principles for U.S. Post-Conflict Policy in Iraq and served as an advisor to USAID's project on “Options for Developing a Long-term Sustainable Iraqi Oil Industry.” She also served as project director for the joint Baker Institute/CFR task force Strategic Energy Policy: Challenges in the $21^{\text {st }}$ century. Prior to joining the Baker Institute, Ms. Jaffe was the senior editor and Middle East analyst for Petroleum Intelligence Weekly, a respected oil journal. Ms. Jaffe has written for a variety of publications and also appeared on a variety of television news programs. Ms. Jaffe is widely published in academic journals and has received the 1994 Award for Excellence by the International Association for Energy Economics, was a 2003 Women in Energy-Americas honoree and is a member of the Council on Foreign Relation. 



\section{Market Structure in the New Gas Economy: Is Cartelization Possible?}

Ronald Soligo and Amy Myers Jaffe

\section{Introduction}

Natural gas is quickly becoming one of the most important sources of world energy supply. The increasing importance of natural gas to modern economies raises new concerns regarding the security of gas supplies and the potential formation of a gas cartel similar to OPEC.

Figure 1 shows the growth in trade of gas over the last 30 years. This growth has been propelled by environmental concerns as well as by new technologies that have increased the viability of gas as a substitute for oil and coal, such as the combined cycle gas generator, that has significantly increased efficiency of producing electricity from gas, and new technologies in transportation, liquefaction and regasification of natural gas that has significantly lowered the cost of LNG.

Figure 1

\section{World Gas Trade}

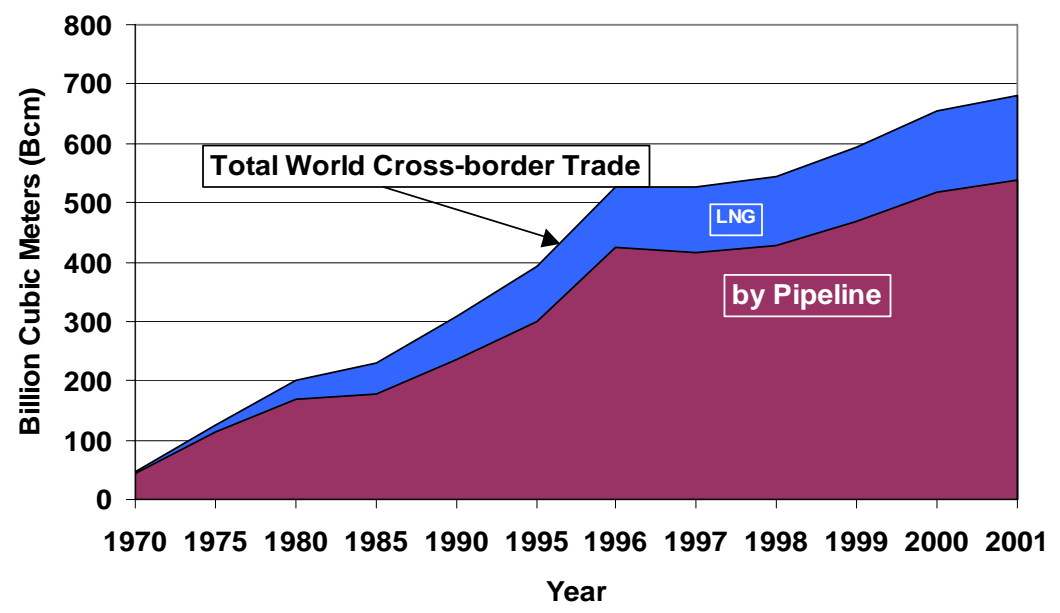

Source: BP, Cedigaz 
In addition to growth in the volume of trade and the share of gas in world energy use, the nature of the international gas market itself is changing. Heretofore, the market for natural gas outside of the U.S. has been characterized by bilateral contracts between suppliers and buyers. The risks inherent in large upfront investment costs in either pipelines or in tankers and onshore liquefaction and gasification terminals for LNG was ameliorated by long term contracts that tied gas from a specific field to consumption in a particular market. Because transportation costs, especially for LNG, were relatively high, the level of international trade in gas was limited.

In recent years, as a result of technological improvements that have lowered the cost of LNG and long-distance pipelines, the volume of gas traded in international markets is rapidly increasing. This increased liquidity in the market has promoted the emergence of a spot (non-contract) LNG market. This development is similar to that which has emerged in the market for oil over the last three decades.

As gas becomes a more important input to industrialized economies and the volume of gas traded in international markets increase, large consuming countries will begin to focus increasingly on the security and availability of their gas supplies. In addition, given the apparent similarities between the development of oil and gas markets, the question arises as to whether the structure of the gas market will evolve towards that prevailing in the market for crude oil. Concern for maintaining a secure supply of reasonably priced natural gas, which up to now has taken a back seat to its sister fuel, will increasingly be viewed as a vital national interest. This change is bound to influence the "geopolitics of natural gas". This paper will investigate key variables that might influence this geopolitics and postulate consumer countries response to the new reality of a gasfed world.

\section{Framing the Issues}

Two key issues are likely to drive the development of gas geopolitics. One relates to the concerns of gas importers for "gas security.” The second issue relates to whether a cartel similar 
to the Organization of Petroleum Exporting Countries (OPEC) will emerge in the gas market. Both of these issues are only just now starting to appear on the world stage.

In May 2001, The Gas Exporting Countries Forum (GECF) held its first ministerial meeting in Tehran with the aim to enhance consultation and coordination among gas producers. The meeting included Algeria, Brunei, Iran, Indonesia, Malaysia, Nigeria, Oman, Qatar, Russia, Norway and Turkmenistan. Although the GECF ministers' announcement emphasized that they did not intend to pursue a production sharing agreement and quota system during the initial meeting, certain individual members of the group have debated the merits of exercising some form of market influence or control. ${ }^{1}$ Such ideas have been gaining momentum since the group's first session.

A second official ministerial meeting of GECF was held in 2002 in Algiers and attended by 13 countries including Bolivia, Egypt, Libya, and Venezuela, which did not attend the first meeting in Tehran. Norway and Turkmenistan did not the second meeting. In 2003, GECF held a third ministerial meeting in Doha, Qatar, with 14 members in attendance including Algeria, Brunei, Egypt, Indonesia, Iran, Libya, Malaysia, Nigeria, Oman, Qatar, Russia, Trinidad and Tobago, the United Arab Emirates, Venezuela and one observer, Norway. The same grouping attended this year's meeting in Cairo and agreed to establish an executive bureau.

Producer associations both national and international are quite common. They serve as a forum to discuss common problems and provide useful information to members. They can also serve a useful public function of lobbying for regulatory changes to enhance the development of their industry. These associations can also work against the public interest - if they collaborate to raise prices or lobby for regulatory changes that restrict competition. It remains unclear what sort of association the GECF will become.

The discussion in the paper is divided into 6 sections. The first section deals with the concentration of gas resources and exports. Section two discusses the security of gas supply 
relative to its geographical location and concentration of supply. The remaining sections investigate the options for the creation and policies of a Gas OPEC, taking into considerations studies of the historical experience of oil OPEC.

Key findings of the paper are:

a) The overall distribution of world natural gas reserves is more concentrated than the distribution of oil resources in the sense that the countries with the largest gas reserves have a larger share of world reserves than is the case for oil. For example, the two countries with the largest gas reserves, Russia and Iran, have roughly $45 \%$ of world natural gas reserves while the two countries with the largest oil reserves, Saudi Arabia and Iraq, have 36\% of world oil reserves. The five-country concentration ratio for the two fuels is roughly the same at $62 \%$. However, the regional concentration of gas resources is more diverse. Middle East countries hold only $36 \%$ of natural gas reserves - as opposed to $65 \%$ of oil reserves. The former Soviet Union represents a second equally important region for gas production and exports.

b) Over the long term, gas exports may eventually become concentrated in the hands of just a few major producers. However, it will take many years to work off a plethora of supplies from within major consuming regions and small competitive fringe producers.

c) The Gas Exporting Countries Forum has too many members with competing interests to constrain effectively new capacity expansion projects in the immediate term. It is likely to be at least two decades before they can assert sustained monopoly power in world gas markets. It might be possible, however, for a large gas producer(s) to gain short term rents in particular markets by manipulating availability of immediate supplies.

d) As world LNG markets become more liquid, it will be feasible for the emergence of a “swing producer” to emerge in spot LNG trade. In the intermediate term, Qatar is best position to assume this role due to its current plans to add quickly to its spare export capacity and its relatively greater financial freedom given its small population compared to its resource wealth. In the longer term, Russia may play a critical price arbitrage role between eastern and western 
markets, with the potential to extract rents from its dominant position in the market, but its ability to play a role as swing producer will be constrained by its large population, high costs and more diversified industry that includes a mix of private and public companies.

\section{Distribution of Reserves and Exports}

In order to understand how the world's major powers will respond to the increased dependence on gas as a fuel, it is important to start with an analysis of the availability and location of world gas resources. A comparison with oil illuminates the discussion, for, as in the case of oil, the location of the largest gas deposits is not coincident with the location of demand. This lack of coincidence has necessitated significant international movements of both oil and gas. Future growth in the relative use of gas will result in even more international trade in both pipeline gas and LNG.

It is often said that gas resources are more varied and dispersed than oil and therefore sufficient concentration does not exist for the effective creation of a gas cartel. However, the facts are more nuanced as shown in Tables 1 and 2 that show the geographical distribution of natural gas reserves and net exports for both oil and natural gas. 


\begin{tabular}{|c|c|c|c|c|c|}
\hline \multicolumn{6}{|c|}{ Table 1: Distribution of Oil and Gas Reserves 2003} \\
\hline Oil & & & Natural Gas & & \\
\hline & & Cumulative & & & Cumulative \\
\hline Country & Share & Share & Country & Share & Share \\
\hline Saudi Arabia & $25.3 \%$ & $25.3 \%$ & Russia & $30.5 \%$ & $30.5 \%$ \\
\hline Iraq & $11.1 \%$ & $36.4 \%$ & Iran & $14.8 \%$ & $45.3 \%$ \\
\hline Iran & $9.7 \%$ & $46.1 \%$ & Qatar & $9.2 \%$ & $54.5 \%$ \\
\hline Kuwait & $9.6 \%$ & $55.6 \%$ & Saudi Arabia & $4.1 \%$ & $58.6 \%$ \\
\hline UAE & $6.1 \%$ & $61.7 \%$ & UAE & $3.9 \%$ & $62.4 \%$ \\
\hline Russia & $5.7 \%$ & $67.4 \%$ & United States & $3.4 \%$ & $65.8 \%$ \\
\hline Venezuela & $5.1 \%$ & $72.5 \%$ & Algeria & $2.9 \%$ & $68.7 \%$ \\
\hline Nigeria & $3.1 \%$ & $75.6 \%$ & Venezuela & $2.7 \%$ & $71.4 \%$ \\
\hline Libya & $2.9 \%$ & $78.5 \%$ & Nigeria & $2.3 \%$ & $73.7 \%$ \\
\hline China & $2.3 \%$ & $80.8 \%$ & Iraq & $2.0 \%$ & $75.7 \%$ \\
\hline United States & $2.2 \%$ & $83.0 \%$ & Indonesia & $1.7 \%$ & $77.3 \%$ \\
\hline Other FSU & $2.0 \%$ & $85.1 \%$ & Australia & $1.6 \%$ & $79.0 \%$ \\
\hline Qatar & $1.9 \%$ & $87.0 \%$ & Norway & $1.4 \%$ & $80.4 \%$ \\
\hline Mexico & $1.7 \%$ & $88.6 \%$ & Malaysia & $1.4 \%$ & $81.7 \%$ \\
\hline Algeria & $1.3 \%$ & $89.9 \%$ & Turkmenistan & $1.3 \%$ & $83.0 \%$ \\
\hline Brazil & $0.9 \%$ & $90.8 \%$ & Uzbekistan & $1.2 \%$ & $84.2 \%$ \\
\hline Norway & $0.9 \%$ & $91.7 \%$ & Kazakhstan & $1.2 \%$ & $85.4 \%$ \\
\hline Angola & $0.9 \%$ & $92.6 \%$ & Netherlands & $1.1 \%$ & $86.5 \%$ \\
\hline Indonesia & $0.6 \%$ & $93.1 \%$ & Canada & $1.1 \%$ & $87.6 \%$ \\
\hline Oman & $0.6 \%$ & $93.7 \%$ & Egypt & $1.1 \%$ & $88.7 \%$ \\
\hline Canada & $0.5 \%$ & $94.2 \%$ & China & $1.0 \%$ & $89.7 \%$ \\
\hline Rest of world & $6.8 \%$ & $100.0 \%$ & Rest of World & $10.3 \%$ & $100.0 \%$ \\
\hline
\end{tabular}

On a reserves basis, distribution of gas resources is indeed highly concentrated at the top of the distribution, with $45 \%$ of natural gas reserves lying in only two countries: Russia and Iran. Oil reserves are actually slightly less concentrated - the two countries with the largest reserves hold 36\%. A similar relationship holds when comparing the three and four country concentration ratios. However, the five country concentration ratio is roughly the same for oil and gas - in both cases the top 5 countries hold $62 \%$ of total world reserves. Going further down the list shows that gas reserves are slightly less concentrated than oil reserves. For example, the 10 countries with the largest reserves hold $81 \%$ of oil reserves but only $76 \%$ of gas reserves. 
An important difference in terms of the geographical concentration is that while the largest oil reserves are all in Middle East countries, the largest gas reserves are in Russia. Middle East countries are still very important, holding $36 \%$ of natural gas reserves - as opposed to $65 \%$ of oil reserves. The specific countries in the Middle East that have the largest gas reserves, Iran and Qatar, are different from those with the largest oil reserves, Saudi Arabia and Iraq. Saudi Arabia, Iran and UAE are in the top 5 spots in both the gas and oil lists. Thus, the gas world is less concentrated in the sense that there are two geographically separate regions of high reserves as opposed to oil where the Middle East is of unparalleled importance.

Resource concentration only tells part of the story, however. The market power of a country will be reflected in its share of total output - or more importantly, exports. We employ exports rather than production as a measure of the dominance of countries in world markets since market power is more likely to be related to its share of total internationally traded gas and oil than its share of total output. For example, the U.S. is amongst the largest producers of both oil and gas but is a net importer of both. The smaller Gulf producers, on the other hand, have more modest output levels but are significant players in the export markets.

Table 2 shows the distribution of current net exports. Again, contrary to popular perception, the geographical concentration of gas exports is higher than that for oil. Saudi Arabia, the largest exporter of oil has $16.4 \%$ of the export market while Russia, the largest gas exporter, has $28.1 \%$. The largest four oil exporters have only a 39.2\% share while the largest four gas exports have a $62.8 \%$ share.

The higher concentration of gas exports is due to the relatively undeveloped state of gas relative to oil markets as well as the low level of LNG as compared with pipelines as a means for exports. For example, the largest gas exporters, Russia and Canada are countries connected by pipeline to large gas consumers - Europe and the U.S. - with well-developed gas distribution infrastructure. 


\section{Table 2: Distribution of Oil and Gas Exports 2001}

\begin{tabular}{|c|c|c|c|c|c|}
\hline \multirow[t]{2}{*}{ Oil } & \multicolumn{5}{|c|}{ Natural Gas } \\
\hline & & Cumulative & & & Cumulativ \\
\hline Country & Share & Share & Country & Share & e Share \\
\hline & 16.4 & & & 28.1 & \\
\hline Saudi Arabia & $\%$ & $16.4 \%$ & Russia & $\%$ & $28.1 \%$ \\
\hline & & & & 17.0 & \\
\hline Russia & $9.7 \%$ & $26.1 \%$ & Canada & $\%$ & $45.1 \%$ \\
\hline Norway & $7.0 \%$ & $33.1 \%$ & Algeria & $9.5 \%$ & $54.6 \%$ \\
\hline Venezuela & $6.1 \%$ & $39.2 \%$ & Norway & $8.2 \%$ & $62.8 \%$ \\
\hline Malaysia & $5.7 \%$ & $44.9 \%$ & Turkmenistan & $6.3 \%$ & $69.1 \%$ \\
\hline Iran & $5.4 \%$ & $50.3 \%$ & Indonesia & $5.3 \%$ & $74.4 \%$ \\
\hline UAE & $4.7 \%$ & $55.1 \%$ & Netherlands & $4.5 \%$ & $78.9 \%$ \\
\hline Nigeria & $4.3 \%$ & $59.3 \%$ & Malaysia & $3.4 \%$ & $82.4 \%$ \\
\hline Iraq & $4.2 \%$ & $63.5 \%$ & Uzbekistan & $2.9 \%$ & $85.3 \%$ \\
\hline Kuwait & $4.0 \%$ & $67.6 \%$ & Qatar & $2.6 \%$ & $87.9 \%$ \\
\hline Mexico & $3.5 \%$ & $71.1 \%$ & United Kingdom & $1.6 \%$ & $89.5 \%$ \\
\hline Algeria & $2.9 \%$ & $74.0 \%$ & Australia & $1.6 \%$ & $91.1 \%$ \\
\hline Libya & $2.6 \%$ & $76.7 \%$ & Brunei & $1.5 \%$ & $92.5 \%$ \\
\hline United Kingdom & $1.9 \%$ & $78.6 \%$ & Nigeria & $1.4 \%$ & $94.0 \%$ \\
\hline Oman & $1.9 \%$ & $80.5 \%$ & Oman & $1.2 \%$ & $95.2 \%$ \\
\hline Qatar & $1.8 \%$ & $82.3 \%$ & UAE & $1.1 \%$ & $96.3 \%$ \\
\hline Canada & $1.7 \%$ & $84.0 \%$ & Argentina & $1.0 \%$ & $97.3 \%$ \\
\hline Angola & $1.5 \%$ & $85.5 \%$ & Burma & $0.8 \%$ & $98.1 \%$ \\
\hline & & & Trinidad & & \\
\hline Kazakhstan & $1.3 \%$ & $86.8 \%$ & Tobago & $0.6 \%$ & $98.7 \%$ \\
\hline Argentina & $0.9 \%$ & $87.7 \%$ & Bolivia & $0.6 \%$ & $99.4 \%$ \\
\hline Colombia & $\begin{array}{l}0.8 \% \\
11.5\end{array}$ & $88.5 \%$ & Denmark & $0.5 \%$ & $99.9 \%$ \\
\hline Rest of World & $\%$ & $100.0 \%$ & Libya & $0.1 \%$ & $100.0 \%$ \\
\hline
\end{tabular}

Table 3 compares the share of reserves and production of various regions for both oil and natural gas. The table also shows the ratio of the production share to the reserve share which gives some indication of the degree to which a region's resources are being exploited. 


\begin{tabular}{|c|c|c|c|c|c|c|}
\hline \multicolumn{7}{|c|}{ Table 3: Reserve and Production Shares for Oil and Gas } \\
\hline \multirow[b]{3}{*}{ North America } & \multicolumn{2}{|c|}{ OIL } & \multicolumn{2}{|c|}{ Gas } & \multirow{2}{*}{\multicolumn{2}{|c|}{$\begin{array}{r}\text { Ratios P/R } \\
\text { Oil Gas }\end{array}$}} \\
\hline & \multicolumn{2}{|c|}{ Reserves Production } & \multirow{2}{*}{$\begin{array}{l}\text { Reserves } \\
4.6 \%\end{array}$} & \multirow{2}{*}{$\begin{array}{l}\text { Production } \\
30.8 \%\end{array}$} & & \\
\hline & $4.4 \%$ & $19.8 \%$ & & & 4.5 & 6.7 \\
\hline Central \& S. Americ & a $7.3 \%$ & $9.4 \%$ & $4.5 \%$ & $4.4 \%$ & 1.3 & 1.0 \\
\hline Western Europe & $1.6 \%$ & $9.0 \%$ & $3.5 \%$ & $11.3 \%$ & 5.6 & 3.2 \\
\hline Eastern Europe & Q & & & & & \\
\hline FSU & $7.9 \%$ & $11.6 \%$ & $35.7 \%$ & $28.0 \%$ & 1.5 & 0.8 \\
\hline Middle East & $64.7 \%$ & $29.1 \%$ & $36.0 \%$ & $9.3 \%$ & 0.4 & 0.3 \\
\hline Africa & $9.3 \%$ & $10.5 \%$ & $7.6 \%$ & $5.3 \%$ & 1.1 & 0.7 \\
\hline Asia \& Oceania & $4.7 \%$ & $10.7 \%$ & $8.1 \%$ & $11.0 \%$ & 2.3 & 1.4 \\
\hline
\end{tabular}

As the table shows, North America and Western Europe are areas where gas reserves are being fully developed. These two areas have only $8.1 \%$ of gas reserves but produce $42.1 \%$ of gas output. For oil they have 6\% of reserves and produce $28.8 \%$ of output. The Middle East is an area where gas resources are underexploited even relative to oil. While the Middle Eastern share of gas reserves is 36\%, their share of output is only 9.3\%. Africa and Eastern Europe and the former Soviet Union (essentially Russia) are also areas where resources are relatively underdeveloped. The significance of these data is that gas production has largely been geared to provide for local domestic consumption and export to nearby consumer countries that can be easily connected by pipeline. As the cost of LNG continues to fall, many countries will join producers like Indonesia, Algeria, Malaysia and Australia to further develop their gas resources for export.

\section{Security of Supply: Geographic Location}

The concentration of oil resources in the Middle East has been a major feature of international oil markets for over three decades. While there are many volatile areas around the world that produce oil, there is no other area with the same concentration of production as the Middle East. The probability that there would be simultaneous disruptions in several oil producing areas outside the Middle East that could knock out significant oil supplies beyond 3 million barrels a day are relatively small. By contrast, markets tend to think of the Middle East as an area where 
events in one country can easily impinge on the fortunes of others. In general, these perceptions of interdependence mean that events in the Middle East will appear to, and have over recent history, threaten large quantities of oil and hence produce larger price reactions than one would expect from disruptions or instability in other non-Middle East producing areas. Moreover, growing dependence on oil from one supply region, in this case, the Middle East, strengthens the monopoly power of those suppliers with consequences for longer run prices.

With respect to natural gas, Tables 1 and 3 show that the location of gas reserves are more diversified regionally than oil. The Middle East, the source of much instability, accounts for only $36 \%$ of world gas reserves while accounting for almost $65 \%$ of oil reserves. Even to the extent that political disturbances in the Middle East can easily spread from one country to another, such disturbances will likely have a smaller effect on gas markets than on oil markets. This is particularly true in the near term as several major Middle East gas reserve holders, notably Saudi Arabia, Iran and Iraq, are not likely to become major gas exporters for some time - given economic and political disadvantages they face. The fact that large reserves are located in Russia is a major source of geographic diversification and stability for world gas markets. Russia has its own areas of conflict but they are distant from the location of gas reserves. In addition, potentially destabilizing incidents in the Middle East and Russia are unlikely to be correlated.

In terms of energy markets as a whole, this shift to gas will be helpful to diversifying the geographic concentration of energy supply. Not only are the two major, prolific gas resource producing regions, the Middle East and the former Soviet Union not contiguous, but within the Middle East region, gas reserves are not concentrated in the same countries as oil reserves. Iran and Qatar have 69\% of Middle East gas reserves but only 17.9\% of oil. Saudi Arabia and Iraq account for only $56.3 \%$ of regional oil reserves but only $16.9 \%$ of regional gas reserves. 


\section{The Potential for a Gas Cartel: Lessons from Oil Markets}

As mentioned above, several gas exporting countries joined together to form the Gas Exporting Countries Forum (GECF) in 2001. Ostensibly, the Forum is to focus on "promoting policy discussion and exploring avenues of technical cooperation"3. Yet, more than half of the 14 participants in GFEC are members of OPEC and several other GECF participants have occasionally provided varying support for production sharing cutbacks implemented by OPEC but involving non-OPEC participation. So, can GECF evolve into an effective cartel with significant power? That is the issue discussed in this section.

The GECF has already tried, unsuccessfully, to exercise some collective influence in the European market. The first example is its attempt to create a unified response to liberalization in Europe. At the second official meeting of GECF in Algiers in early 2002 a working group, including Russia and Algeria, was set up to discuss gas supply issues with the European Union (EU). Following such working group sessions, Algeria and Russia made clear that they wanted to band with other gas exporters to resist EU attempts to outlaw destination clauses that prevent buyers from reselling gas. ${ }^{4}$ The option to resell gas is a pivotal mechanism for market arbitrage and efficiency that can restrict sellers from segregating markets and exercising monopolistic influence. $^{5}$

In another example, Egypt, at the third Ministerial meeting of GECF in Qatar in February 2003, proposed that the exporter group initiate a gas pricing change in Europe by ending the link to crude oil prices in hopes to create better market penetration for gas. ${ }^{6}$ Both of these proposals have so far not advanced further, and a gas cartel remains at a theoretical stage.

Cartels are difficult to create and maintain and especially so when there are more than just a few members. The reasons are well known. The cartel must decide how much to restrict output which must be less than what would be collectively produced in the absence of the cartel. Allocating production quotas among members is difficult because each member has different 
needs, ambitions and uncertain bargaining power. Once agreement is reached, however, each member can benefit at the expense of others by cheating on the quota. The larger the number of members and more liquid the market, the more difficult it is to detect who is doing the cheating. There is also the problem of how the cartel can punish a cheater even if caught. Finally, the cartel must deter entry into the industry; otherwise its share of the market will shrink along with its power to set price or other market conditions.

OPEC is generally considered a textbook case of a cartel although there remains considerable disagreement on its efficacy. Mabro ${ }^{7}$ surveys the literature, including other surveys, and points out the myriad of explanations -other than OPEC manipulation-- that have been offered for major swings in oil prices as well as the many models that have been put forth to explain OPEC behavior. As Smith ${ }^{8}$ shows, the debate continues. Despite the ambiguity regarding just how much market power OPEC or Saudi Arabia exhibited at any particular time, several facts remain clear. Oil prices are significantly above the marginal costs of production in some of the largest OPEC producers. ${ }^{9}$ It is also accepted that in situations where investment in capacity lags growth in demand, OPEC can temporarily raise prices by modestly restricting output. It is also understood that Saudi Arabia has at times fulfilled a special role in maintaining price discipline within OPEC. By maintaining excess capacity, Saudi Arabia is a "swing producer" that can flood the market and drive down oil prices to punish members who may exceed their quotas on the one hand and increase production to moderate price increases and hence limit new entry by fringe producers on the other. ${ }^{10}$

Moreover, it is clear that any cartel would be more effective at raising and maintaining prices if it controlled capacity growth of its members as opposed to trying to persuade individual producers to produce less than their capacity. Excess capacity will, of course, occur from time to time as demand fluctuates, but the ability to set prices in the longer term would be facilitated by coordinating capacity expansion even more so than output levels. 
Over the years, Saudi Arabia's enormous reserves and high oil revenue earnings capability relative to its population has facilitated its role as disciplinarian. For example, Saudi Arabia has oversupplied oil markets twice in face of stiff market competition, once in 1985 when non-OPEC production was on a sharp upward path and again in 1997 when Venezuela was embarked on an aggressive policy to increase its market share. The 1985 price decline lasted for several years although it should be noted that some authors, citing interviews and documents from the Reagan Administration, have suggested that the prolonged depression of prices was also engineered, in collaboration with the U.S., in order to deny revenue to the Soviet Union so as to put stress on their ability to match the growing U.S. defense expenditures of the Reagan era and finance the war in Afghanistan. ${ }^{11}$ It is not clear that Saudi Arabia could execute the same sort of policy today given its much larger population and revenue needs and its growing public debt. ${ }^{12}$ In addition, the revival of the Russian oil industry and future re-emergence of Iraq as a significant oil exporter may diminish the Saudi role as the dominant force in oil markets.

The need to control capacity expansion and the dominant role of Saudi Arabia as an enforcer came together in the late 1990s in the Saudi reaction to Venezuelan capacity expansion in the 1990s. Venezuela had been actively expanding its oil production capacity through an opening up to foreign direct investment by American oil companies initiated in 1992. The program was expected to take Venezuela's oil production as high as 7 million barrels a day by 2010, a level almost rivaling Saudi Arabia. For a period of many months in 1998-1999, Saudi Arabia publicly warned Venezuela to stop overproducing and to abandon its plans to expand its oil market share. It threatened to initiate an oil price war to eliminate the incentives for continued investment in Venezuela and to "punish" the Venezuelan government. Venezuela failed to heed Saudi warnings, and as markets softened in 1998, Saudi Arabia refused to cut backs it production as oil prices moved into a free fall. When oil prices reached a low of $\$ 8$ a barrel in 1999, Venezuela was forced to concede. Ironically, in part related to financial troubles, Venezuela experienced a change in government, and the new Venezuelan government immediately trimmed back plans to expand oil production capacity. In fact, continued political unrest in Venezuela, in the aftermath of the entire financial debacle stimulated by the 1998 oil price crash, led to an oil workers strike that has set Venezuela's state oil industry back tremendously. Venezuela's production capacity has fallen from 3.7 million barrels a day prior to the election of Hugo 
Chavez in 1999 to just over 2 million b/d today, contributing dramatically to the tightening of oil markets in recent years and related high prices. ${ }^{13}$ A Harvard University's John F. Kennedy School of Government executive seminar report on "Oil and Security" in May 2003 concluded that this Saudi strategy, "has been costly for countries attempting to challenge the position of Saudi Arabia. The Saudis have responded aggressively and ruthlessly to protect their leading role in the world market." ${ }^{14}$

Ironically, OPEC's ability to limit capacity expansion has been aided by sanctions levied by Western countries against several OPEC members: Iran, Iraq, and Libya, which among other effects, discouraged investment in these key producing countries. ${ }^{15}$ Without those sanctions, it is unlikely that OPEC could have controlled capacity expansion to the level of success seen in recent years. ${ }^{16}$ There were other factors limiting investment in capacity. For example, the rapidly expanding populations in many OPEC countries created intense pressures on state treasuries for expanded social services, leaving less money to be spent on oil sector expansion. ${ }^{17}$

In the late 1980s, OPEC had planned capacity expansions to a total of 32.95 million barrels a day targeted for 1995, but by early 1997, OPEC capacity had reached only 29 million barrels a day. Iran, Libya and Iraq all failed to achieve their production targets. ${ }^{18}$ All these factors have contributed to a general stagnation of OPEC capacity since the late 1990s. In fact, as table 4 below shows, OPEC capacity has actually fallen since 1979, not increased. 
Table 4 OPEC Sustainable Capacity- Historical to Present

\begin{tabular}{|c|c|c|c|c|c|c|c|c|}
\hline Member Country & 1979 & 1983 & 1990 & 1997 & 1998 & 2000 & 2001 & 2003 \\
\hline Saudi Arabia & 10.84 & 11.30 & 8.00 & 9.65 & 9.50 & 9.50 & 9.90 & 10.15 \\
\hline Iran & 7.00 & 3.00 & 3.10 & 3.70 & 3.70 & 3.75 & 3.80 & 3.80 \\
\hline Iraq & 4.00 & 1.50 & 3.60 & 2.30 & 2.80 & 2.90 & 3.05 & 2.20 \\
\hline Kuwait* & 3.34 & 2.80 & 2.40 & 2.40 & 2.40 & 2.40 & 2.40 & 2.50 \\
\hline UAE & 2.50 & 2.90 & 2.20 & 2.40 & 2.40 & 2.40 & 2.45 & 2.50 \\
\hline Qatar & 0.65 & 0.65 & 0.40 & 0.71 & 0.72 & 0.73 & 0.75 & 0.75 \\
\hline Venezuela & 2.40 & 2.50 & 2.60 & 3.45 & 3.30 & 2.98 & 3.10 & 2.50 \\
\hline Nigeria & 2.50 & 2.40 & 1.80 & 2.00 & 2.05 & 2.10 & 2.30 & 2.30 \\
\hline Indonesia & 1.80 & 1.60 & 1.25 & 1.40 & 1.35 & 1.35 & 1.30 & 1.15 \\
\hline Libya & 2.50 & 2.00 & 1.50 & 1.45 & 1.45 & 1.45 & 1.45 & 1.45 \\
\hline Algeria & 1.23 & 1.10 & 0.75 & 0.88 & 0.88 & 0.88 & 0.88 & 1.15 \\
\hline Total & 38.76 & 31.75 & 27.60 & 30.34 & 30.55 & 30.44 & 31.38 & 30.45 \\
\hline Call on Opec & 34.01 & 16.65 & 22.20 & 27.59 & 25.85 & 30.04 & 28.23 & 29.20 \\
\hline Spare Capacity & 4.75 & 15.10 & 5.40 & 2.75 & 4.70 & 0.40 & 3.15 & 1.25 \\
\hline
\end{tabular}

(Source: Baker Institute estimates, Hetco Trading, PIW)

\section{Modeling OPEC}

There are a number of different ways in which economists have attempted to model OPEC in order to explain its behavior. The "dominant firm" model is one that captures some important aspects of OPEC. The model divides industry producers into one large firm (or cartel) and many other smaller firms that can be called the competitive fringe. Figure 2 below, drawn from Perloff ${ }^{19}$ illustrates the model. 
Figure 2: Dominant Firm Equilibrium

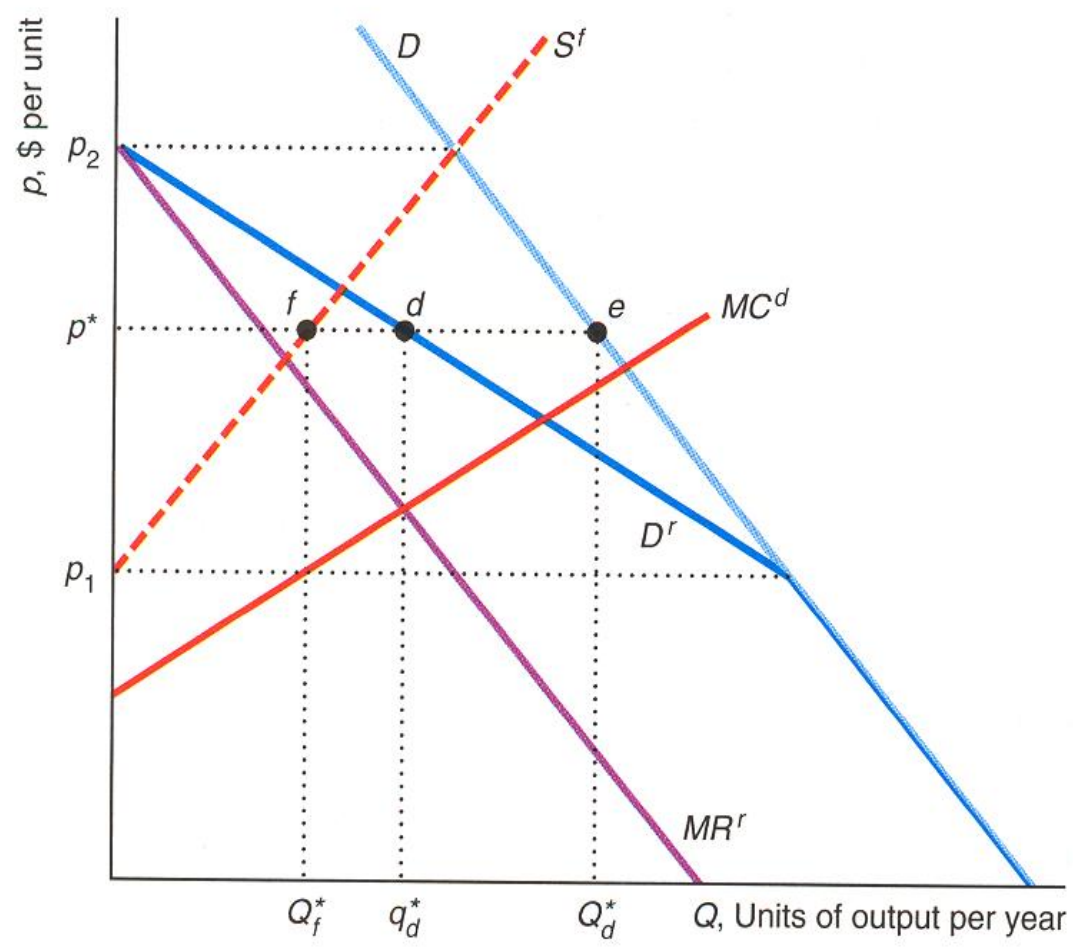

The world demand curve for oil is given by the curve labeled $\mathrm{D}$. The supply curve of the competitive fringe is given by S'. The demand curve facing the dominant firm (OPEC) is the residual demand curve constructed by taking, for each price, total world demand and fringe supply. That curve, shown as $D^{r}$ in the diagram gives the amount of oil that OPEC can sell at each price. Having monopoly power, OPEC will then maximize its profits by setting output at the point where marginal revenue is equal to marginal cost. In the diagram $M R^{r}$ is the cartel's marginal revenue curve while $M C^{d}$ shows its marginal cost curve. OPEC produces $q_{d}^{*}$, and sets price equal to $P^{*}$. The fringe produces $Q_{f}^{*}$ and total output is $Q_{d}^{*}$.

The market power of the cartel with monopoly power is measured by the extent to which it can set price above marginal cost and is given by the equation:

$$
\frac{P}{M C}=\frac{1}{1+\left(1 / \varepsilon_{d}\right)}
$$


Market power is determined by the elasticity of demand facing the cartel - which is a weighted average of the elasticity of aggregate demand and the elasticity of fringe supply where the weights are the inverse of the market share of the dominant firm and the ratio of outputs on fringe producers to that of the dominant firm respectively. It is given by the equation:

$$
\varepsilon_{d}=\varepsilon \times\left(Q_{d} / q_{d}\right)+\varepsilon_{f} \times\left(Q_{d}-q_{d}\right) / q_{d}
$$

Where $\varepsilon_{d}$ is the elasticity of the residual demand curve

And $\varepsilon$ is the elasticity of the aggregate demand curve

$\varepsilon_{f}$ is the elasticity of the competitive fringe

Holding all else constant, pricing power of OPEC is enhanced the more inelastic the aggregate demand curve and the fringe supply and the larger its market share.

This model is useful to the analysis of OPEC because it highlights the importance of the competitive fringe, as well as other factors, in limiting the market power of OPEC. Efforts to raise prices by restricting cartel output will be limited if the higher prices result in a large increase in supply from non-OPEC members or in large decreases in oil consumption. The mid 1980s demonstrated the importance of both of these factors when, in response to the sharp oil price increases in the early and late 1970s, non-OPEC production increased rapidly at the same time that demand decreased, in part, because consumers learned how to economize on energy. The fall in demand was aggravated by the recession that occurred at the same time.

The dominant firm framework can also be used to gain insight as to the future path of oil prices. The International Energy Agency and other forecasters are projecting that non-OPEC production could reach peak levels as early as $2010 .^{20}$ This might be interpreted to suggest that the elasticity of supply of the fringe will be reduced in the future- that there will be a smaller supply response by non-OPEC producers if prices should increase in the future as compared with the past. As discussed above, a reduction in the supply elasticity of the fringe will reduce the elasticity of demand facing OPEC for its oil and increase OPEC's market power. So, as the potential for 
increasing fringe supplies over time diminishes, the result will be to give OPEC (Saudi Arabia or the OPEC core) more pricing power.

Many forecasts of future world oil markets contend that OPEC's share of the world oil market will markedly increase in the coming decades. For example, the IEA estimates that OPEC's share of total supply will increase from 38\% in 2000 to $48 \%$ in 2020. This increase in market share would in and of itself increase the monopoly power of OPEC. However, as Gately ${ }^{21}$ points out, IEA projections for OPEC supply are calculated as a residual between world demand and non-OPEC supply. These estimates do not take into consideration whether incentives will be in place for OPEC to actually increase its supply to the high forecasted levels. Indeed, Gately argues that the IEA forecasts that OPEC will meet rising demand are not consistent with the interests of OPEC producers themselves. A firm with monopoly power has no incentive to produce where the marginal revenue of output is negative. Gately argues that that is precisely what is implied for OPEC by the IEA forecasts.

Gately's work suggests that the IEA may be overly optimistic about future oil prices, which are assumed to remain flat to 2010 and then gradually increase. Indeed, the recent rise in oil prices is already inconsistent with the IEA assumption although it is still not clear whether current prices are a short term aberration or a glimpse of what lies ahead.

It is important to note that Gately does not discuss the issue of whether OPEC members can agree to future quotas. So while it may be in their collective interest to restrict future output, it is not certain that they will be able to cooperate to do so. In favor of Gately's thesis is the fact that in a growing market, each member country will be able to increase output even if its share remains unchanged. Collusion is generally easier in a non-zero sum environment. However, if one or more major OPEC members were to make a large drive towards rapid capacity expansion, this would make it more difficult for the producer group to reach strong agreements. 


\section{Prospects for a Gas OPEC}

The requirements for an effective cartel are that there should be a relatively small number of producers who control a substantial share of the market, that it must be able to establish and enforce production quotas, control capacity expansion and restrict entry of new producers at the fringe. Controlling capacity expansion is a preferred way of restricting output of cartel members since capacity will limit the ability to cheat and the extent of actual production cheating. ${ }^{22} \mathrm{New}$ entrants, or capacity expansion by existing producers who are not in the cartel, will undermine the effectiveness of the cartel unless their size is small relative to market growth.

The data in Table 2 showing country shares of the gas export market suggest that GECF could evolve into an institution with market power similar to that of OPEC. Seven counties, fewer than the membership of OPEC, currently account for almost $79 \%$ of the gas export market! That suggests that there already is a sufficient number of producers to form a price setting cartel. However, three of those seven, Canada, Norway and the Netherlands would be unlikely to join a gas producers' cartel given their ties to the industrialized West and thereby conflicting interests. The remaining four exporters would control only $49.2 \%$ of exports. Still, adding the next three largest exporters would bring market share to 58\%. However, without Russia, the share of the remaining 6 countries falls to only $30 \%$ - probably too little to wield much market power. It seems, therefore, that Russian participation is critical for a successful cartel.

But while concentration of current exports is fairly high, the potential for a significant increase in output and exports from other countries is also very large. Table 1 showed that there were a large number of countries with significant gas reserves - say with at least $1 \%$ of the world's reserves. With a reduction in transport costs and the further development of a gas market, many of these reserves will be developed without significant price increases. In the context of the dominant firm model, the elasticity of supply of fringe producers is large thus limiting the pricing power of a small group of producers - even including Russia. Eventually, as in oil, gas production in the fringe will peak, and the market power of the cartel would be enhanced. The timing of these 
events will be determined by the rate at which gas demand grows and gas reserves both within the cartel and in the competitive fringe are developed.

There are additional impediments to the formation of an effective gas cartel. One challenge is the competition of gas with other fuels. Unlike oil where there are few substitutes in the transportation sector, natural gas must compete with coal, oil, hydroelectric and nuclear power in most of its uses. In terms of the dominant firm model, the existence of many substitutes for gas increases the elasticity of demand for gas, both in the aggregate and for cartel output. A higher elasticity of demand will translate into reduced market power of the cartel. Improvements in the safety of nuclear power and reductions in the cost of clean-coal technologies will, over time, lower the upper limit to gas (and oil) prices that a cartel can set without triggering massive defections to alternative energy sources. But it must be remembered that a time lag is likely to exist between the time at which a gas cartel can assert its power to accrue rents and the time it will take natural gas users to make the capital investment to shift to facilities that can utilize alternative fuels.

The interdependence between gas and oil markets presents an additional challenge for a gas producers group. There will be an overlap of members who already participate in the OPEC oil cartel and those who would be members of a gas cartel. But there will be some countries that will be a member of only one or the other. As the gas market develops further and gas supplies become a more readily available alternative to oil in many parts of the world, price competition between gas and oil may increase. This could complicate the politics of both cartel organizations since the largest gas producers are not necessarily the countries with the largest oil production potential. Gas on oil competition between new major gas producers and the major oil producers in particular growth markets such as China or Japan could cause market share rivalries and political tensions that could weaken the market power of both organizations. Cooperation between the two cartels would be difficult because a larger number of members in the larger coalition would make it unwieldy. On the other hand, Russia will be a major player in both markets and the link between oil and gas prices may induce it to join or at least cooperate with OPEC. 
Certain OPEC oil countries have recognized this possible future connection between oil and gas. In the official communique of the second summit of heads of state and government of OPEC member countries on 28 September 2000, OPEC recognized a group interest in promoting both oil and gas use, as opposed to just oil use. The OPEC document said the cartel should seek to promote the "use of both oil and gas in circumstances where they can be substituted for other fuels that are recognized as being damaging to the global environment." ${ }^{23}$ This language was interpreted by analysts to mean that OPEC heads of state were concerning themselves with the future of regulating gas sales and prices as well as just oil markets.

As an aside, it should be noted that from the point of view of oil consumers, the prospect of growing competition between oil and gas on a worldwide basis would be welcomed. To the extent that Gately is correct that OPEC will not have the incentives to produce the quantity of oil that is forecast by IEA projections, the growth of gas production and exports would ameliorate some of the bullish price effects on oil that is implicit in his analysis.

Privatization of gas reserves and the gas transport network in producer countries may also present an impediment to the formation of a successful gas cartel. It will be easier for national, state-owned, producers to participate in a cartel than for privately owned firms that might have different objectives from the state. If a number of private Russian gas producers emerge, it will be more difficult to reconcile their conflicting corporate ambitions with OPEC-related production quotas.

On the other hand, it must be noted that the experience of the Texas Railroad commission which pro-rationed production shares in Texas with a significant impact on U.S. oil prices in the 1960s suggests that such coordination is not impossible. Nonetheless, Russia's participation in a gas cartel will be facilitated to the extent that Gazprom (now merged with state oil firm Rosneft) will maintain its monopoly in gas production and transmission. However, even if ownership of production is liberalized, continued Russian state control of transmission capacity alone could force producers to cooperate. 
Liberalization of energy markets in consumer countries will also hinder cartel development to the extent that it fosters competition not only between gas and other energy sources but also between different sources of gas. From the perspective of an importing country, having different, competing sources of gas effectively increases the elasticity of demand facing a cartel and reduces its market power. For example, even Algeria and Russia's limited goals to roll back EU strictures on resale contracts proved too difficult in the European context given competitive pipeline supply from Northern Europe and a variety of LNG suppliers such as Nigeria and Egypt that could quickly take over market share in Spain. Moreover, even Algeria itself was conflicted because of the attractive opportunity to expand its market share via the Italian pipeline system in nascent Eastern European markets, weakening its market leverage with Italian buyers.

Controlling capacity expansion is probably more important to an effective gas cartel than it is for oil. The very high costs of building the infrastructure for a gas project puts great pressure on owners to fully utilize their capacity. But controlling capacity investments will be difficult. For example, the large number of producers currently participating in GECF would have to agree to some system of staggering new capacity investment projects. Countries that were required to postpone such investments would be penalized in the sense that they would not be able to immediately benefit from the revenues that would be generated by monetizing those reserves. The present discounted value of their reserves would be reduced. Also, many countries face pressing needs for development funds and will be subject to pressures to exploit their resources as quickly as possible. A fair system of staggering investments would require that those countries at the head of the queue would compensate those who were relegated to positions further on down. The large number of members might mean that many large resource-owning countries would have to wait a long time for a turn to expand capacity. The Rice World Gas Trade Model, for example, shows that demand growth will not make space for major expansion of Greenfield Iranian and Saudi gas resources until after 2020. ${ }^{24}$

Finally, an effective cartel requires an ability to enforce discipline amongst members to prevent cheating on quotas. As we have seen, in OPEC this role has been performed by Saudi Arabia 
who maintained excess capacity so that it could be the swing producer - to moderate price increases to discourage new entrants and to lower prices in order to punish transgressors.

The role of swing producer will be much more costly for a gas producer than in the case of oil because of the much higher fixed costs associated with gas projects. For gas, the swing producer would have to maintain excess liquefaction and LNG tanker capacity or gas pipeline capacity as well extra production and storage capacity. Given the costs, the role may not be attractive and consequently could go unfilled. Fawzi ${ }^{25}$ points out that

"In the oil industry, it is estimated that a 1 percent capacity surplus in worldwide oil production (assuming an investment of \$3,000 per daily barrel) would cost about $\$ 2.2$ billion. By contrast, creating a 1 percent surplus in world-wide gas production, assuming that the entire 1 percent was brought to market as LNG, would have a price tag of about $\$ 13.8$ billion (in field development, liquefaction and tankers)”

An option is to have a core group in the cartel that would act collectively as swing producers so as to spread the costs over a larger number of members. But such a plan would mean that the costs of decision making increases. Moreover, the potential for agreement diminishes as the number of members increases. The need for collective action would result in a weaker cartel than having a single country fulfill the role of swing producer. The absence of any swing producer would require that the cartel find other ways to enforce agreements; otherwise it would become irrelevant if faced with cheating which is very likely.

To the extent that one country would fulfill the role of swing producer, the likely candidates for such a role in a gas cartel would be countries with the largest reserves. Two such candidates are Russia or Qatar although in each case, there are factors that may inhibit them from playing such a role.

There are several reasons why Russia might not play the roll of swing producer. First, the cost of excess capacity includes the opportunity cost of foregone public revenues from gas production 
and export - the value of the public goods and services that are not produced as a result of excess capacity. Russia has a very large population and many developmental and social needs. There will be great pressure over the next several years to produce at capacity in order to generate as much government revenues as possible. Second, gas production might in the future be undertaken with participation by privately owned companies, since state monopoly Gazprom might not be able to meet demand inside Russia and in European markets on its own. Since it will not be in the interest of private companies to maintain excess capacity some mechanism would have to be developed to force them to do so. As discussed above, private ownership is not a bar to cartelization but regulating private firms is not as easy as dealing with a single state monopoly. The retention of control of the export infrastructure by the government or government enterprise could provide the impetus for production sharing rules. ${ }^{26}$

In theory, Qatar may be better placed to play the role of swing producer even though its reserves are substantially below that of Russia. Qatar reserves are very high relative to its population and the need to maintain output to generate adequate revenue is not as urgent as in the case of Russia. Qatar will export LNG which does not require an extensive dedicated transport infrastructure as does pipeline transport and because of its geographic position, will be well placed to move supplies to all three major markets in Asia, Europe and the U.S. Finally, given its first mover advantages and prolific reserves, Qatar "has the lowest exploration and development costs for gas of any region in the world”27. However, according to projections from the Rice World Gas Model (see Table 5 below), Qatar will have a relatively small share of world gas exports - in the 3-4 percent range until 2030. Still, its share of LNG exports will be approximately 10 percent which, given the inflexibility of pipeline gas, may be sufficient to give Qatar enough leverage to influence world gas prices.

Other large reserve holders such as Saudi Arabia, Iran and Iraq are unlikely candidates for the swing producer role because they will not become significant exporters until after 2030 Nigeria, despite its modest reserves, is predicted to have a significant share of world exports by 2020 (6.2\%). This share, driven by LNG exports to the U.S., will increase to $7 \%$ by 2030 . Nigeria is 
unlikely to be a swing producer, however, because of its large population and pressing revenue needs.

Table 5, which shows forecasts from the Rice World Gas Model, predicts that gas development in Russia will continue to be a pivotal factor in global gas market development. ${ }^{28}$ Russia has the advantage that it lies between two of the world's largest energy consuming areas, Europe to the West and East Asia to its East. It is also advantaged by the fact that it can reach these markets easily by pipeline. Its largest potential competitors, primarily in the Middle East, will have to rely on higher cost, more distant LNG to compete in those markets.

\begin{tabular}{|llllll|}
\hline \multicolumn{7}{|l}{ Table 5: Share of Total Gas Exports } & & & \\
& 2002 & 2010 & 2020 & 2030 & 2040 \\
Russia & $29.0 \%$ & $16.7 \%$ & $18.1 \%$ & $17.3 \%$ & $19.4 \%$ \\
Kazakhstan & $2.1 \%$ & $8.2 \%$ & $5.4 \%$ & $2.5 \%$ & $0.6 \%$ \\
Turkmenistan & $5.5 \%$ & $3.8 \%$ & $3.1 \%$ & $3.6 \%$ & $4.3 \%$ \\
Canada & $13.9 \%$ & $8.0 \%$ & $3.4 \%$ & $0.0 \%$ & $0.0 \%$ \\
Algeria & $11.9 \%$ & $10.9 \%$ & $6.7 \%$ & $2.0 \%$ & $0.3 \%$ \\
Nigeria & $1.5 \%$ & $2.3 \%$ & $6.2 \%$ & $7.0 \%$ & $5.3 \%$ \\
Angola & & $0.1 \%$ & $0.5 \%$ & $0.9 \%$ & $0.8 \%$ \\
Indonesia & $6.7 \%$ & $5.0 \%$ & $5.0 \%$ & $5.3 \%$ & $4.4 \%$ \\
Malaysia & $3.7 \%$ & $4.3 \%$ & $3.1 \%$ & $1.1 \%$ & $0.0 \%$ \\
Brunei & $1.5 \%$ & $1.2 \%$ & $1.1 \%$ & $1.1 \%$ & $0.5 \%$ \\
Australia & $1.6 \%$ & $1.6 \%$ & $2.8 \%$ & $7.0 \%$ & $7.6 \%$ \\
Iran & $0.0 \%$ & $0.0 \%$ & $0.0 \%$ & $2.5 \%$ & $6.5 \%$ \\
Qatar & $2.9 \%$ & $3.3 \%$ & $3.9 \%$ & $6.8 \%$ & $8.5 \%$ \\
Saudi Arabia & $0.0 \%$ & $0.0 \%$ & $0.0 \%$ & $4.1 \%$ & $7.2 \%$ \\
Norway & $8.6 \%$ & $7.4 \%$ & $6.3 \%$ & $5.4 \%$ & $4.5 \%$ \\
Greenland & $0.0 \%$ & $0.0 \%$ & $0.0 \%$ & $0.0 \%$ & $1.9 \%$ \\
Trinidad \& Tobago & $1.2 \%$ & $2.3 \%$ & $1.6 \%$ & $0.7 \%$ & $0.0 \%$ \\
Venezuela & $0.0 \%$ & $0.0 \%$ & $1.1 \%$ & $3.7 \%$ & $3.1 \%$ \\
Rest of World & $9.8 \%$ & $25.0 \%$ & $31.8 \%$ & $29.1 \%$ & $25.2 \%$ \\
Source: Rice World Gas Model & & & & \\
\hline
\end{tabular}

Table 5 shows, that Russia's share of the gas export market will decline from current levels but will remain the highest worldwide even out to 2040. It has, and will continue to have, such a 
commanding share of the gas trade that it alone could exert some monopoly power. The export share from other countries in the Former Soviet Union, primarily Turkmenistan and Kazakhstan, whose export routes are currently controlled by Russia, will increase significantly in the short run from a current combined level of 7.6 percent to 12.0 percent by 2010 and then will decline gradually.

Because of other LNG suppliers who are closer to end-user markets and pipeline gas competitors, the Rice model projects that Qatar's share will hover around 3-4 percent of the export market until after 2020 despite its massive resource base. Iran and Saudi Arabia, as indicated above, will be late developers. They are not expected to be exporters until after 2025.

The results of the Rice world gas Model are based on the assumption that the pattern and level of investments in gas development and production are motivated by strictly economic criteria, in particular that investment occurs where and when it is most efficient. The relative economic attractiveness of Russian pipeline gas compared to distant LNG promotes a modeling outcome showing Russian gas coming on line to an overwhelmingly greater extent than the resources of the Middle East. For the next two decades, Russia’s capability to exercise significant market power will be limited to it ability to appropriate the difference in costs between its pipeline gas and the higher cost of LNG from the Middle East and Africa. In the context of our earlier discussion of the dominant firm model, the elasticity of supply of the fringe, in this case including LNG capacity from the Middle East and Africa, is relatively inelastic over a small range of prices. But once prices reach the level that would cover these LNG costs, the supply from the competitive fringe becomes very elastic, essentially eliminating any power that the Russians would have to raise prices further.

Over the longer term, as gas production capacity peaks in the various regions containing more limited gas production potential, including regions in or near industrialized economies, cooperation between LNG suppliers and Russia will become increasingly attractive. By 2020, the Rice gas model predicts that Russia in combination with Algeria, Nigeria, Indonesia, Qatar and Venezuela will account for 48.7 percent of world exports potentially giving this group considerable market power. Russia's incentive to cooperate with these other producers that are 
members of OPEC is enhanced by the fact that oil and gas are close substitutes, and overall market power could be strengthen by cooperating on pricing for both fuels. Thus, it might be in Russian interests to collude with all OPEC members to coordinate and attempt to set prices for both oil and natural gas.

\section{Conclusion}

The foregoing discussion suggests that any gas producer group is unlikely to exercise significant market power in the near term. While Russia has a large share of the export market currently, its sales are directed at Europe where there are several alternative sources of supply- especially from North Africa and Northern Europe. In the intermediate term, say to 2020, Russia's dominance is predicted to decline but a small group consisting of Russia, and several members of OPEC (Algeria, Nigeria, Indonesia, Qatar and Venezuela) could command as much as forty-nine percent of the export market by 2020 .

Initially, the ability of this group, or a subset of it, to set price will be constrained by the fact that there are many countries with sufficient undeveloped resources to provide for many competing sources of supply - at the right price. However, eventually, a point will be reached in the long term, say beyond 2030, when much of the alternative supplies would have peaked, and those countries that have large reserves will be in a very strong market position. It would seem to be in the interests of Russia to cooperate with OPEC to at least limit gas on oil competition. The extent to which this small group of oil and gas exporters will be able to exercise monopoly power will be determined, among other factors, by technological improvements that will affect the cost and attractiveness of other competing fuels such as coal, nuclear or renewable energy.

Options available to consumer countries are limited and well known. Deregulating their own energy sectors, to permit utilities more freedom in setting prices, in choice of technology and in contracting with fuel suppliers will have the effect of increasing the elasticity of their demand for gas and limiting the market power of gas sellers. Consuming countries can also actively promote the technologies that will increase competition between gas and alternative energy sources. The 
potential emergence of significant monopoly power by gas exporters seems to be at least a decade or two away, permitting a realistic time frame for pursuing those new technologies to replace natural gas as it becomes more subject to the influence of a gas cartel.

\footnotetext{
${ }^{1}$ Gas Exporters Forum Holds First Annual Meeting in Tehran MEES Vol. XLIV No. 22, May 28, 2001.

${ }^{2}$ It should be noted that there are several, not entirely consistent, estimates of oil reserves. The estimates used here are from World Oil. The Oil and Gas Journal estimates include some 174.8 billion barrels of bitumen from Alberta's oil sands. Including those reserves puts Canada in second place after Saudi Arabia. The IEA's estimates put Russia in second place with 14.3\% of the world's oil reserves.

${ }^{3}$ Quote from Ali Aissaoui “Gas-Exporting Countries: Towards 'Cartelization?, Oxford Energy Forum VOL. XLV, No 32, Aug 12, 2002.

${ }^{4}$ Club House: Yusufov Proposes Gas Exporter Club, Petroleum Intelligence Weekly, March 14, 2002 .

${ }^{5}$ Soligo, Ronald and Amy Myers Jaffe, "A Note on Saudi Arabian Price Discrimination", Energy Journal, Jan 2000.

${ }^{6}$ Mixed Reviews for Egypt’s Pricing Plan, Petroleum Intelligence Weekly, Feb 12, 2003

${ }^{7}$ Mabro, Robert (1998). “OPEC Behavior 1960-1998: A Review of the Literature”. The Journal of Energy Literature IV(1): 3-27.

${ }^{8}$ Smith, James L. "Inscutable OPEC?: Behavioral Tests of the Cartel Hypothesis", and

"Distinguishable Patterns of Competition, Collusion, and Parallel Action”, MIT CEEPR working papers: http://web.mit.edu/ceepr/www/workingpapers.htm.

${ }^{9}$ Adelman, M. A. The Genie Out of the Bottle: World Oil since 1970, The MIT Press, Cambridge, 1995.

${ }^{10}$ Rapporteur's Report, Harvard University Oil and Security Executive Session, May 14. 2003, Environment and Natural Resources Program, Belfer Center for Science and International Affairs .

${ }^{11}$ Schweizer, Peter, "Victory: The Reagan Administration's Secret Strategy that Hastened the Collapse of the Soviet Union” (1994).

12 See Ed Morse and James Richard, The Battle for Energy Dominance” Foreign Affairs, March/April 2002.

${ }^{13}$ David Bird, Saudis Not About to Concede Any Markets, October 16, 1997, Dow Jones \& Co. 10:25 GMT; Saudis Subdue Doubters by Plowing Ahead with Crude Production, The Oil Daily, January 8, 1998; Also, see discussion on this subject in Rapporteur's Report, Harvard University Oil and Security Executive Session, May 14. 2003, Environment and Natural Resources Program, Belfer Center for Science and International Affairs .
} 
${ }^{14}$ Rapporteur's Report, Harvard University Oil and Security Executive Session, May 14. 2003, Environment and Natural Resources Program, Belfer Center for Science and International Affairs.

${ }^{15}$ For a detailed discussion on sanctions impact on investment, see Meghan L. O’Sullivan, "Shrewd Sanctions: Statecraft and State Sponsors of Terrorism” Brookings Institution Press, Washington DC, 2003.

${ }^{16}$ Soligo, Ronald, Amy Myers Jaffe, Peter Mieszkowski, Energy Security, Baker Institute working paper, available at www.bakerinstitute.org.

${ }^{17}$ Jaffe, Amy, “Geopolitics of Oil, Encyclopedia of Energy, Elsevier, 2004

${ }^{18}$ Iran had aimed to reach 4 million b/d, Libya 1.6 million b/d and Iraq 4.5 million barrels a day, but were constrained at 3.8 million b/d, 1.4 million b/d and 1.2 million b/d respectively. See Political, Economic, Social, Cultural, and Religious Trends in the Middle East and the Gulf and Their Impact on Energy Supply, Security and Pricing, Baker Institute study, available at www.bakerinstitute.org.

${ }^{19}$ Perloff, Jeffrey M (2004). Microeconomics, Third Edition, Pearson Education Inc. pg. 384.

${ }^{20}$ World Energy Outlook IEA, 2002; Deffeyes, Kenneth, Hubbert's Peak, Princeton University Press: Princeton NJ 2001.

${ }^{21}$ Gately, Dermot, (1995). “Strategies for OPEC’s Pricing and Output Decisions,” The Energy Journal 16(3): 1-38.

Gately, Dermot, (2001). "How Plausible is the Consensus Projection of Oil Below \$25 and Persian Gulf Oil Capacity and Output Doubling by 2020,” The Energy Journal 22(4): 1-27. Gately, Dermot, (2004). “OPEC’s Incentives for Faster Growth,” The Energy Journal 25(2): 7596.

${ }^{22}$ Authors interviews with the organizers and participants of GFEC, Vienna September 2003.

${ }^{23}$ Communique, available at www.opec.org. Analysts commented at the meeting that this reference was the result of exploratory OPEC discussion of the idea to draw natural gas into its portfolio. (see LaFranchi, Howard, OPEC Hopes to Settle Price Swings, Christian Science Monitor, Setember 27, 2000) .

${ }^{24}$ Hartley, Peter and Kenneth B. Medlock III, “A Global Market for Natural Gas? Prospects 2035”, working paper, James Baker Institute for Public Policy, Rice University, Houston, May 2004.

${ }^{25}$ Fawzi, Aloulou, "Qatar LNG 2010 and the UD Gas Market: Setting a New Global Cost Benchmark”, U.S. Department of Energy, Energy Information Administration, Washington, DC July 2004.

${ }^{26}$ For a more detailed discussion of the future options for the Russian gas industry, see the U.S.Russia Commercial Energy Summit Executive Seminar Report, available at www.bakerinstitute.org.

${ }^{27}$ Fawzi, op cit.

${ }^{28}$ Hartley and Medlock op cit. 